\title{
A comprehensive review of nanoparticles applications in the oil and gas industry
}

\author{
Mortadha T. Alsaba' ${ }^{1} \cdot$ Mohammed F. Al Dushaishi $^{2} \cdot$ Ahmed K. Abbas $^{3}$
}

Received: 6 September 2019 / Accepted: 23 December 2019 / Published online: 2 January 2020

(c) The Author(s) 2020

\begin{abstract}
With the increased attention toward nanotechnology and their innovative use for different industries including but not limited to food, biomedical, electronics, materials, etc, the application of nanotechnology or nanoparticles in the oil and gas industry is a subject undergoing intense study by major oil companies, which is reflected through the huge amount of funds invested on the research and development, with respect to the nanotechnology. Nanotechnology has been recently investigated extensively for different applications in the oil and gas industry such as drilling fluids and enhanced oil recovery in addition to other applications including cementing and well stimulation. In this paper, comprehensive literature was conducted to review the different applications of nanotechnology in the oil and gas industry. A summary of all nanoparticles used along with a detailed analysis of their performance in improving the targeted parameters is comprehensively presented. The main objective of this review was to provide a comprehensive summary of the different successful applications of nanotechnology and its associated challenges, which could be very helpful for future researches and applications.
\end{abstract}

Keywords Nanoparticles $\cdot$ Nanotechnology $\cdot$ Nanofluids $\cdot$ Review

\section{Introduction}

The concept of nanotechnology was inspired after Richard Feynman talk "There's Plenty of Room at the Bottom" at the California Institute of Technology in 1959 (Gribbin and Gribbin 2018) where he discussed the idea in which scientists would be capable of handling individual atoms and molecules. The term "nanotechnology" was then first introduced and used by Professor Norio in 1974 (Norio 1974), where it was defined as" the production technology to get extra high accuracy and ultra-fine dimensions, i.e., the preciseness and finesse of the order of $1 \mathrm{~nm}$ (nanometer) 10-9 in length". In addition, it was stated that "nanotechnology" mainly involves "the processing of separation, consolidation, and deformation of materials by one atom or one molecule"

Mortadha T. Alsaba

m.alsaba@ack.edu.kw

1 Petroleum Engineering Department, Australian College of Kuwait, P.O. Box 1411, 13015 Safat, Kuwait

2 School of Engineering, Texas A\&M International University, Laredo, TX 78041, USA

3 Iraqi Drilling Company, P.O. Box: 941, Al Borjsea, Basra 19312, Iraq
(Norio 1974). Since then, different researchers started using the term "nanotechnology". The general definition of "nanotechnology" as per the National Nanotechnology Initiative (NNI) (National Nanotechnology Initiative 2000) is "science, engineering, and technology conducted at the nanoscale, which is about 1 to $100 \mathrm{~nm}$ ".

The increased interest in nanotechnology-related research and development is clearly reflected through the huge amount of money invested in nanotechnology R\&D. The NNI alone has received almost $\$ 27$ billion including the proposed budget for 2019 (National Nanotechnology Initiative 2018). Another example is the huge investment of $\$ 350$ million by Massachusetts Institute of Technology (MIT) for the state-of-the-art nanoscale research center named "MIT. nano" (Chandler 2014). NanoMech, which is a leading company in nanomanufacturing, has received $\$ 10$ million investment from Saudi Aramco Energy Ventures (SAEV).

Nanotechnology has been used in different industries including but not limited to food, biomedical, electronics, materials, etc. One of these industries is the oil and gas industry, where the revolution of nanotechnology applications covered different areas in both upstream and downstream. A quick look at the recent published applications related to nanotechnology reveals a wide range of

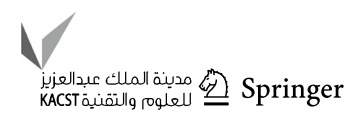


nanoterminology such as nanoparticles (Sensoy et al. 2009; Ogolo et al. 2012; Hafiz et al. 2018), nanocomposite (Lecolier et al. 2005; Pourafshary et al. 2009; Chauhan and Ojha 2016; Kumar et al. 2018), nanomembrane (Seland et al. 1992; Kong and Ohadi 2010; Shen and Sheng 2016; Guo et al. 2013; Ventura et al. 2017; Folio et al. 2018), nanosensors (Sudarshan et al. 2001; Piantanida et al. 2013), nanorobot (Singh and Bhat 2006; Joshua 2014), nanofluids (Kanj et al. 2009; Alomair et al. 2014; Gerogiorgis et al. 2017; Yuan and Moghanloo 2018).

A lot of questions are always raised when proposing a new application of nanotechnology in the oil and gas industry, these questions include; why nanoparticles? What makes nanoparticles better than the conventional solution? The answer to these questions can be summarized as follows: Nanoparticles have some distinctive properties such as their size and their relatively large surface-to-area ratio when compared to the same volume that is made from larger particles, which can result in a higher magnitude of reactivity or interaction with adjacent surfaces, hence enhancing the properties of the carrying fluid with a lower amount of the same material. In addition, the small size of nanoparticles empowers them in terms of transportation through the small pores in the formation, which will help the used nanoparticles in flowing easily inside the pore spaces. Therefore, the use of nanoparticles in the oil and gas industry can be justified due to their above-mentioned unique characteristics.

With this growing attention and development of nanotechnology in the oil and gas industry, which can be clearly observed through the number of related publications (Fig. 1), it is crucial to review the available application and summarize what has been done up to date.

The main objective of this paper is to provide the reader with a comprehensive summary of the successful application of nanotechnology and its associated challenges. This paper highlights, in particular, the different applications of nanoparticles (NPs) in enhancing related parameters to enhanced oil recovery (EOR), drilling fluids, cementing, and well stimulation.

\section{Applications of nanoparticles in oil and gas industry}

In this section, a comprehensive review of the most recent applications of nanoparticles in the oil and gas industry including EOR, drilling fluids, cementing, and well stimulation, is discussed. The discussion includes a tabulated summary of the used NPs, the investigated parameters, and their effectiveness in terms of improving the targeted parameters.

\section{Enhanced oil recovery applications}

Due to the fact that two-thirds of the oil in place is left behind after the primary and secondary recovery (Bai 2008), and based on the significant increase observed in oil recovery using enhanced oil recovery techniques (EOR), which includes chemical injection, thermal recovery, and gas injection, a good number of researches have been conducted to improve the different EOR techniques by the addition of nanoparticles. Table 1 shows a summary of the recent investigations on the application of nanoparticles to enhance EOR techniques along with the targeted parameters and the investigated nanoparticles. The main objective of these investigations is to study the effect of nanoparticles in improving oil recovery by improving one of the parameters related to oil recovery.

Despite the fact that NPs might improve some parameters, it could also negatively affect some other parameters. Hogeweg et al. (2018) found that zinc oxide tends to form larger particles resulting in injection difficulties. Adding NP to brine or ethanol could result in poor recovery compared to brine or ethanol alone. Injection blockage and settling issues have also been reported previously (Ding et al. 2018). NP
Fig. 1 Number of publications per year (until October 2018)

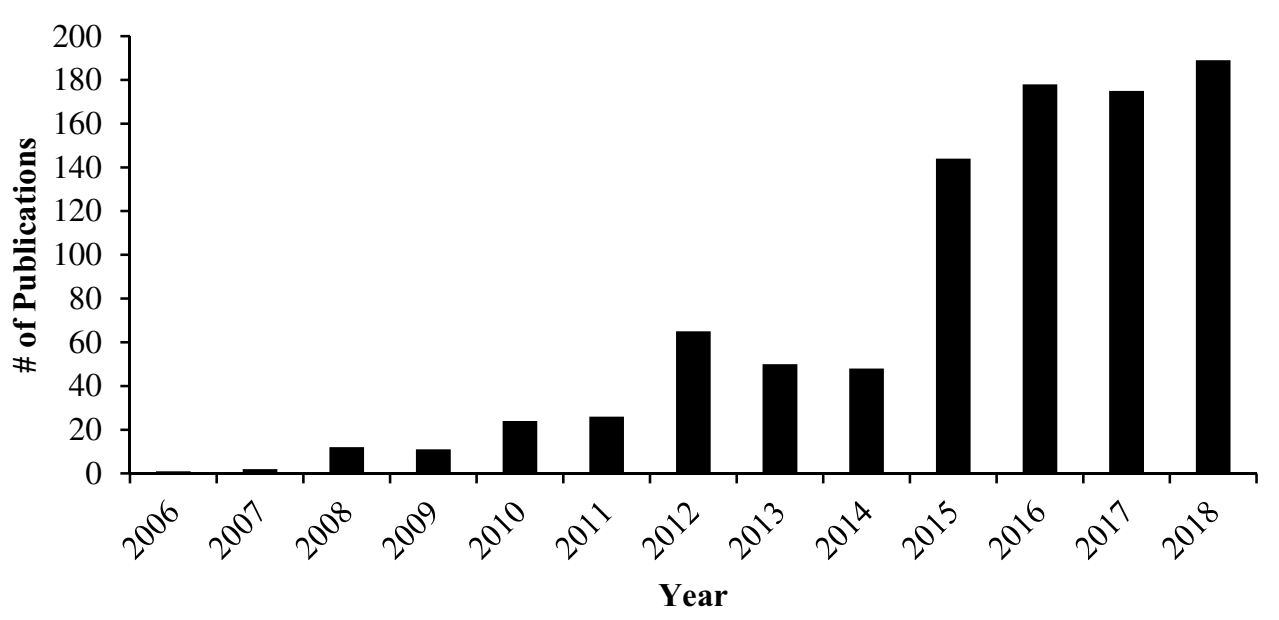


Table 1 Application of nanoparticles for EOR

\begin{tabular}{|c|c|c|}
\hline Investigated NP & Improved parameters & References \\
\hline $\begin{array}{l}\text { Aluminum oxide } \\
\text { Titanium dioxide }\end{array}$ & $\begin{array}{l}\text { Reducing oil viscosity } \\
\text { Improving the stability of the injected water for EOR } \\
\text { application }\end{array}$ & Hogeweg et al. (2018) \\
\hline $\begin{array}{l}\text { Aluminum oxide } \\
\text { Silicon dioxide }\end{array}$ & $\begin{array}{l}\text { Improving oil recovery using low salinity hot water } \\
\text { (LSHW) injection with addition of nanoparticles }\end{array}$ & Ding et al. (2018) \\
\hline $\begin{array}{l}\text { Aluminum oxide } \\
\text { Silicon dioxide } \\
\text { Titanium dioxide }\end{array}$ & $\begin{array}{l}\text { Improving the rheological properties of the injected water } \\
\text { for EOR application } \\
\text { Improving oil recovery }\end{array}$ & Abdullahi et al. (2019) \\
\hline Cellulose nanocrystals (CNCs) & $\begin{array}{l}\text { Conformance control } \\
\text { Stability of oil in water emulsions }\end{array}$ & Pandey et al. (2018) \\
\hline Graphene oxide & Reducing oil viscosity & Elshawaf (2018a) \\
\hline Graphene oxide & $\begin{array}{l}\text { Reduction in oil viscosity } \\
\text { Increasing oil recovery }\end{array}$ & Elshawaf (2018b) \\
\hline Graphene-based zirconium oxide nanocomposite & $\begin{array}{l}\text { Reducing excess water production } \\
\text { Used it as a cross-linker for water shutoff }\end{array}$ & Almohsin et al. (2018) \\
\hline $\begin{array}{l}\text { Magnesium oxide } \\
\text { Aluminum oxide } \\
\text { Zinc oxide } \\
\text { Zirconium oxide } \\
\text { Tin oxide } \\
\text { Iron oxide } \\
\text { Nickel oxide } \\
\text { Hydrophobic Silicon dioxide }\end{array}$ & $\begin{array}{l}\text { Altering wettability } \\
\text { Reducing interfacial tension } \\
\text { Reducing oil viscosity } \\
\text { Reducing mobility ratio } \\
\text { Altering permeability }\end{array}$ & Ogolo et al. (2012) \\
\hline $\begin{array}{l}\text { Nickel oxide/silicon dioxide } \\
\text { Janus nanoparticles }\end{array}$ & $\begin{array}{l}\text { Enhancing oil recovery at low concentration } \\
\text { Reducing formation damage } \\
\text { Reducing interfacial tension, hence increasing oil recovery }\end{array}$ & Giraldo (2018) \\
\hline Polymer-coated nanoparticle & Improving mobility control, altering surface wettability & ShamsiJazeyi et al. (2014) \\
\hline Silicon dioxide & $\begin{array}{l}\text { Increasing sweep efficiency } \\
\text { Improving foam stability for alpha-olefin sulfonate (AOS) } \\
\text { solution } \\
\text { Increasing oil recovery }\end{array}$ & Ibrahim and Nasr-El-Din (2018) \\
\hline Silicon dioxide & $\begin{array}{l}\text { Improving foam stability } \\
\text { Improving mobility reduction factor (MRF) }\end{array}$ & Khajehpour et al. (2016) \\
\hline Silicon dioxide & Improving foam stability & Ajulibe et al. (2018) \\
\hline Silicon dioxide & $\begin{array}{l}\text { Reducing surfactant adsorption on the porous media of an } \\
\text { oil reservoir }\end{array}$ & Suresh et al. (2018) \\
\hline Silicon dioxide & $\begin{array}{l}\text { Improving emulsion with lower surfactant concentration } \\
\text { Improving oil recovery }\end{array}$ & Arab et al. (2018) \\
\hline Silicon dioxide & Reducing oil viscosity & Pinzón (2018) \\
\hline Silicon dioxide & $\begin{array}{l}\text { Improving surfactant properties } \\
\text { Reducing surfactant adsorption on the porous media of an } \\
\text { oil reservoir }\end{array}$ & Zargartalebi et al. (2014) \\
\hline Surface-functionalized nanocellulose & $\begin{array}{l}\text { Improving oil recovery using "green" chemical EOR } \\
\text { through water flooding }\end{array}$ & Wei et al. (2018) \\
\hline
\end{tabular}

could modify the permeability up to a certain limit when all contact surfaces are covered with NP and at that point, a reduction in porosity and absolute permeability would initiate (Ogolo et al. 2012; Druetta et al. 2018).

\section{Drilling fluids applications}

Drilling fluids can be simply defined as a heavy viscous fluid mixture that is used during the drilling stage in order to perform different tasks including lifting the drilled cuttings, controlling the formation pressure, maintaining wellbore stability, etc. Different additives are used to enhance the different properties of drilling fluids such as the rheological properties, filtration properties. There are different limitations that are faced when designing drilling fluids using conventional additives such as the temperature and the additives particle size limitations. Therefore, nanoparticles were investigated extensively to study their applicability 
in overcoming these limitations. A summary of the recent investigations to improve the drilling parameters by means of nanoparticles is given in Table 2.

Based on the review, it was found that high NP concentration is not recommended due to the insignificant performance increase observed between low and high NP concentrations (Alsaba et al. 2018; Mahmoud et al. 2018). High concentration could also result in increasing the particles friction coefficient, which may alter lubricity and hole cleaning efficiency (Alvi et al. 2018). At high temperatures, some NP could result in a negative effect on filtration characteristics. Alsaba et al. (2018) showed that copper oxide has better thermal stability when compared to magnesium oxide and aluminum oxide in terms of rheological properties. In addition, it was found that silicon dioxide NP might increase the pressure losses in bentonite water-based mud (Minakov et al. 2018) due to the increase in the frictional forces.

\section{Cementing applications}

Well cementing, which can be defined as the process of mixing and pumping cement slurry downhole in the annuls and allowing it to cure and bond between the formation and the casing, is a crucial element in well construction. There are at least six common API classes of cement that meet certain requirement such as sulfate resistance or high

Table 2 Application of nanoparticles for drilling fluids

\begin{tabular}{|c|c|c|}
\hline Investigated NP & Improved parameters & References \\
\hline $\begin{array}{l}\text { Aluminum oxide } \\
\text { Copper oxide } \\
\text { Magnesium oxide }\end{array}$ & $\begin{array}{l}\text { Improving rheological properties } \\
\text { Improving filtration characteristics }\end{array}$ & Alsaba et al. (2018) \\
\hline Copper oxide & $\begin{array}{l}\text { Plug nanopores in shale } \\
\text { Improving hole stability }\end{array}$ & Kumar et al. (2018) \\
\hline CNT-polymer nanocomposite & $\begin{array}{l}\text { Improving rheological properties } \\
\text { Improving wellbore stability } \\
\text { Improving filtration characteristics for HPHT drilling application }\end{array}$ & Hafiz et al. (2018) \\
\hline Iron oxide & Improving filtration characteristics & Mahmoud et al. (2018) \\
\hline Iron oxide & $\begin{array}{l}\text { Improving lubricity of drilling fluids } \\
\text { Improving filtration characteristics }\end{array}$ & Alvi et al. (2018) \\
\hline Iron oxide & Improving filtration characteristics at high temperature & Barry et al. (2015) \\
\hline $\begin{array}{l}\text { Multiwall carbon nanotube (MWCNT) } \\
\text { Zinc oxide } \\
\text { Silicon dioxide }\end{array}$ & $\begin{array}{l}\text { Improving heat transfer } \\
\text { Improving rheological properties }\end{array}$ & Hassani et al. (2016) \\
\hline $\begin{array}{l}\text { Multiwall carbon nanotube (MWCNT) } \\
\text { Silicon dioxide }\end{array}$ & $\begin{array}{l}\text { Improving lubricity of drilling fluids } \\
\text { Improving rheological properties } \\
\text { Improving filtration characteristics }\end{array}$ & Ismail et al. (2016) \\
\hline Nanoclay & $\begin{array}{l}\text { Improving filtration characteristics } \\
\text { Reducing electrical resistivity }\end{array}$ & Vipulanandan et al. (2018b) \\
\hline Nanoclay & $\begin{array}{l}\text { Improving rheological properties for synthetic-based drilling fluids } \\
\text { Reducing electrical resistivity }\end{array}$ & Pan et al. (2018) \\
\hline Nanopolymer & $\begin{array}{l}\text { Improving filtration characteristics } \\
\text { Wellbore strengthening application }\end{array}$ & Xu et al. (2013) \\
\hline $\begin{array}{l}\text { Non-modified silica nanoparticles } \\
\text { Sulfonated nanoparticles }\end{array}$ & $\begin{array}{l}\text { Improving sealing of pores } \\
\text { Improving wellbore stability for shale formation }\end{array}$ & Wang et al. (2018) \\
\hline Silicon dioxide & $\begin{array}{l}\text { Improving rheological properties } \\
\text { Improving hole cleaning }\end{array}$ & Gbadamosi et al. (2018) \\
\hline Silicon dioxide & $\begin{array}{l}\text { Improving shale inhibition } \\
\text { Mitigating pore pressure transmission } \\
\text { Improving wellbore stability }\end{array}$ & Yang et al. (2017) \\
\hline Titanium oxide & $\begin{array}{l}\text { Improving rheological properties } \\
\text { Improving thermal and electrical conductivity } \\
\text { Improving filtration characteristics }\end{array}$ & Parizad et al. (2018) \\
\hline $\begin{array}{l}\text { Titanium oxide } \\
\text { Silicon dioxide } \\
\text { Aluminum oxide }\end{array}$ & $\begin{array}{l}\text { Improving rheological properties } \\
\text { Improve hole cleaning }\end{array}$ & Minakov et al. (2018) \\
\hline Zinc titanate & $\begin{array}{l}\text { Improving rheological properties } \\
\text { Improving thermal stability } \\
\text { Improving filtration characteristics }\end{array}$ & Perween et al. (2018) \\
\hline
\end{tabular}


early strength (Mangadlao et al. 2015). Cement additives are added to improve specific parameters such as; density, setting time, filtration, and viscosity. Several studies addressed the use of nanoparticles in well cementing to enhance cement properties. A summary of the wide range of investigated nanoparticles and their effects on cement properties is presented in Table 3.

The curing fluid, such as limewater or water, can greatly affect the cement compressive strength. It was found that cement can be preferably replaced with $2 \%$ aluminum oxide NP when cured in limewater and $1 \%$ aluminum oxide NP when cured in water. However, the addition of the NP can reduce the workability of the cement where different materials need to be added such as plasticizers (Nazari and Riahi 2011). Alkhamis and Imqam (2018) found that graphene nanoplatelets cause a reduction in cement sheath thermal gradient, which may cause thermal cracks when acceding the tensile stress. Experimental evaluation performed by Santra et al. (2012) using multiwalled carbon nanotubes (MWNTs) did not show an improvement in cement mechanical properties.

\section{Well stimulation applications}

Well stimulation can be simply defined as treatments used to enhance the well productivity either by hydraulic fracturing and matrix acidizing to increase the permeability or by increasing the well production. Few investigations showed an improvement in the well stimulation jobs by means of nontechnology. The targeted properties included filtration and rheological properties of the fracturing and acidizing fluid. A short summary of the investigated nanoparticles and their effects is listed in Table 4.

Nasr-El-Din et al. (2013) found that the salt concentration greatly affects the viscoelastic surfactant fracturing fluid including NP and causes some viscosity stability. The addition of magnesium oxide NP causes a decrease in apparent viscosity of the fracturing fluid. Silicon dioxide acid showed different behavior in limestone compared to shale. Fracture conductivity of shale rock showed better improvements when compared to limestone rock (Singh et al. 2018). Fakoya and Shah (2018) found that there is an optimum concentration to improve rheological properties of surfactantbased fluids for hydraulic fracturing applications, where higher concentration was not recommended.
Table 3 Application of nanoparticles for cementing

\begin{tabular}{|c|c|c|}
\hline Investigated NP & Improved parameters & References \\
\hline Aluminum oxide & $\begin{array}{l}\text { Increasing the electrical resistivity } \\
\text { Enhancing the compressive strength }\end{array}$ & Vipulanandan et al. (2018a) \\
\hline Aluminum oxide & $\begin{array}{l}\text { Accelerating the setting time } \\
\text { Improving mechanical properties }\end{array}$ & Deshpande and Patil (2017) \\
\hline Aluminum oxide & Improving mechanical properties & Nazari and Riahi (2011) \\
\hline Graphene nanoplatelets (GNP) & $\begin{array}{l}\text { Improving mechanical properties } \\
\text { Reducing chemical shrinkage }\end{array}$ & Alkhamis and Imqam (2018) \\
\hline Graphene nanoplatelets (GNP) & Improving mechanical properties & Peyvandi et al. (2017) \\
\hline Iron oxide & $\begin{array}{l}\text { Improve sensing properties } \\
\text { Enhancing the compressive strength }\end{array}$ & Vipulanandan et al. (2015) \\
\hline Magnesium oxide & $\begin{array}{l}\text { Accelerating the setting time } \\
\text { Reducing chemical shrinkage }\end{array}$ & Jafariesfad et al. (2016) \\
\hline $\begin{array}{l}\text { MWNTs } \\
\text { Aluminum oxide } \\
\text { Silicon dioxide }\end{array}$ & Accelerating the setting time & Santra et al. (2012) \\
\hline Nanosynthetic graphite & $\begin{array}{l}\text { Improving the early compressive } \\
\text { strength development }\end{array}$ & Ahmed et al. (2018) \\
\hline Silicon dioxide & $\begin{array}{l}\text { Accelerating the setting time } \\
\text { Enhancing the compressive strength } \\
\text { Improving the filtration characteristic }\end{array}$ & Patil and Deshpande (2012) \\
\hline Silicon dioxide & $\begin{array}{l}\text { Accelerating the setting time } \\
\text { Enhancing the compressive strength }\end{array}$ & Pang et al. (2014) \\
\hline $\begin{array}{l}\text { Silicon dioxide } \\
\text { Iron oxide }\end{array}$ & $\begin{array}{l}\text { Improving mechanical properties } \\
\text { Improve sensing properties }\end{array}$ & Li et al. (2004) \\
\hline Silicon dioxide & Improving mechanical properties & Jalal et al. (2012) \\
\hline Silicon dioxide & Improving mechanical properties & Shih et al. (2006) \\
\hline
\end{tabular}


Table 4 Application of nanoparticles for well stimulation

\begin{tabular}{|c|c|c|}
\hline Investigated NP & Improved parameters & References \\
\hline $\begin{array}{l}\text { Magnesium oxide } \\
\text { Zinc oxide }\end{array}$ & Improving the rheological properties of fracturing fluid & Nasr-El-Din et al. (2013) \\
\hline Pyroelectric nanoparticles & $\begin{array}{l}\text { Improving the filtration characteristic } \\
\text { Improving the rheological properties of fracturing fluid }\end{array}$ & Crews and Huang (2008) \\
\hline Silicon dioxide & $\begin{array}{l}\text { Improving the permeability of un-propped fractures } \\
\text { Formation of microencapsulated acid }\end{array}$ & Singh et al. (2018) \\
\hline Silicon dioxide & $\begin{array}{l}\text { Improving the filtration characteristic } \\
\text { Improving the rheological properties of surfactant-based fluids for } \\
\text { hydraulic fracturing applications }\end{array}$ & Fakoya and Shah (2018) \\
\hline Silicon dioxide & $\begin{array}{l}\text { Reducing adsorption capacity } \\
\text { Reducing permeability damage }\end{array}$ & Li et al. (2019) \\
\hline
\end{tabular}

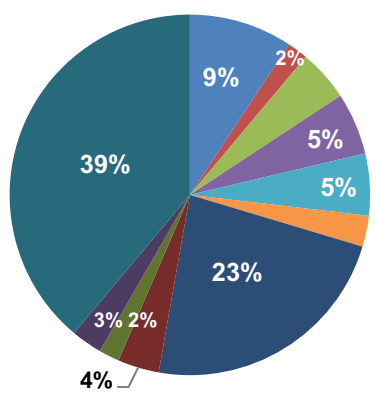

Fig. 2 Distribution of investigation for the different NP in the oil and gas applications

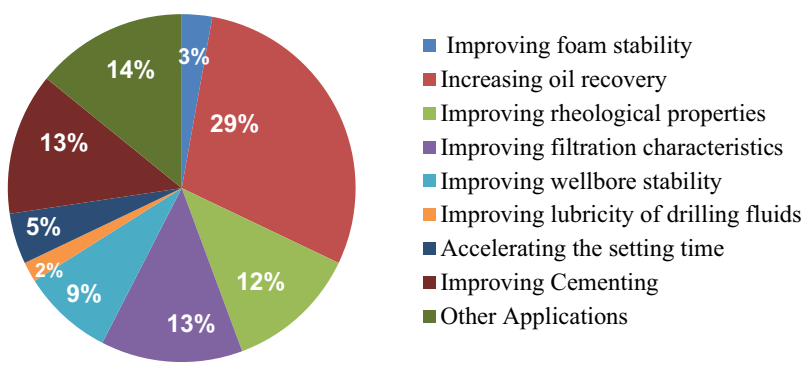

Fig. 3 Targeted property of improvement by means of NP

\section{Statistics about nanoparticles utilization}

Figure 2 shows the distribution of the different nanoparticles investigated in the reviewed literature. It can be clearly seen that silicon dioxide is the most widely used nanoparticles across the oil and gas industry followed by aluminum oxide.

Figure 3 shows the highest targeted property for improvement by means of nanoparticles. It can be clearly seen that nanoparticles have been investigated heavily to study their effect on increasing the oil recovery, which

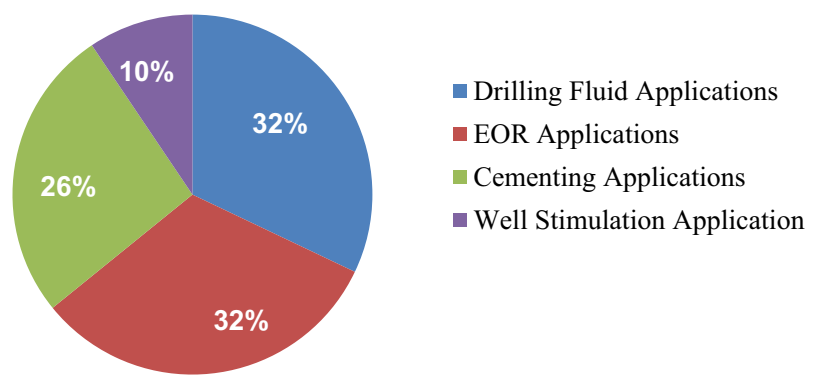

Fig. 4 Percentage of the conducted investigations of nanoparticles across the oil and gas industry

falls down under EOR applications followed by improving the filtration characteristics of drilling fluids and improving cementing, while the least investigated property was found to be the lubricity of drilling fluids.

The percentage of the conducted investigations of nanoparticles across the oil and gas industry for the four applications discussed above is shown in Fig. 4. It can be observed that nanoparticles have attracted researchers in EOR, drilling, and cementing applications. However, the application of nanoparticles for stimulation applications is still not as high as the other applications.

\section{Challenges for nanotechnology in the oil and gas industry}

Despite the growing number of investigations with respect to the high potential of using nanoparticles, there are few challenges that are still controversial. These challenges arise from the following questions; is it economically feasible to replace conventional materials with nanoparticles? Can they result in the same performance on a larger scale (field conditions) similar to the small scale (lab condition)? What is their implication on health, safety, and environment (HSE)? Can they be produced easily and economically? In 
this section, a brief discussion of these challenges will be presented.

In regard to the economic feasibility of nanoparticles versus conventional materials, the main reason behind this question is basically the relatively higher cost of producing some nanoparticles compared to conventional material. The higher cost of production is basically due to the relatively higher embodied energy required to produce nanomaterials per unit mass compared to bulk materials (Kim and Fthenakis 2012). The other reason is the shortage of commercially available nanoparticles for oil and gas applications, despite the fact that a good number of major oil services companies investing a lot in terms of research with respect to nanotechnology.

The other challenge with respect to their effectiveness when applied to a larger scale in the field rather than the laboratory-scale requires better collaboration between oil companies and researchers to validate their performance through pilot testing. It is well known that new technologies require a lot of time before they are applied in the field; however, there are few field trials, which will be discussed in the next section.

When it comes to the impact of nanoparticles on health, environment, and safety, they can be very hazardous and might lead to severe health issues (Nabhani and Tofighi 2010) since they have higher potential of being inhaled or absorbed through skin (Lau et al. 2017) due to their unique properties of nanoparticles in terms of size and surface-toarea ratio. As a result, standards, regulations, recommended practices, and working guidance are being developed by regulatory agencies such as local and international Environmental Protection Agencies (EPA), International Standardization Organization (ISO), American Society for Testing and Materials (ASTM) to reduce or avoid associated risks when handling nanoparticles. Examples of the available standards provided by the National Nanotechnology Initiative (National Nanotechnology Initiative 2019) are given in Table 5.

\section{Does nanoparticles work in the field?}

For the oil and gas industry, in particular, different nanotechnology applications have been proposed based on laboratory experiments. Most of the reported results in the literature showed the potential of nanoparticles in improving the evaluated parameters. Nevertheless, to the best of our knowledge, few field trials have been reported. A summary of the field trials of nanoparticles and nanofluids that shows the potential of nanotechnology applications is given in Table 6 .

\section{Conclusions}

The extensive review over the recent investigations of nanoparticles within the oil and gas industry has shown that nanotechnology has recently emerged as an attractive topic of research and many studies have shown very promising results in terms of their performance and effectiveness. These promising results are due to the distinctive properties of nanoparticles. Despite the high potential of using nanoparticles, there are some challenges such as their economic feasibility and their impact on HSE. Based on the comprehensive literature review, the following conclusions were made:

- The most widely investigated nanoparticles that showed significant improvement for the different applications across the oil and gas industry were found to be the nanosilica $\left(\mathrm{SiO}_{2}\right)$ followed by aluminum oxide $\left(\mathrm{Al}_{2} \mathrm{O}_{3}\right)$, which suggests their high potential in being applied in the field.

- The investigated nanoparticles have shown a significant positive impact on both the rheological and filtration characteristics of drilling fluids as well as improving the thermal stability of drilling fluids.

Table 5 Available standards for nanomaterials (after National Nanotechnology Initiative 2019)

\begin{tabular}{|c|c|}
\hline Document & Title \\
\hline ASTM E2909-13 & $\begin{array}{l}\text { Standard guide for investigation/study/assay tab-delimited format for nanotechnologies (ISA-TAB-nano): standard file } \\
\text { format for the submission and exchange of data on nanomaterials and characterizations }\end{array}$ \\
\hline ISO/TS 80004-1:2010 & Nanotechnologies_vocabulary—part 1: core terms \\
\hline ASTM E249009(2015) & $\begin{array}{l}\text { Standard guide for measurement of particle size distribution of nanomaterials in suspension by photon correlation } \\
\text { spectroscopy (PCS) }\end{array}$ \\
\hline ISO/TR 13014:2012 & $\begin{array}{l}\text { Nanotechnologies-guidance on physicochemical characterization of engineered nanoscale materials for toxicologic } \\
\text { assessment }\end{array}$ \\
\hline ASTM E2524-08(2013) & Standard test method for analysis of hemolytic properties of nanoparticles \\
\hline ISO/TS 12901-1:2012 & $\begin{array}{l}\text { Nanotechnologies—occupational risk management applied to engineered nanomaterials—part 1: principles and } \\
\text { approaches }\end{array}$ \\
\hline ASTM E2996-15 & Standard guide for workforce education in nanotechnology health and safety \\
\hline
\end{tabular}




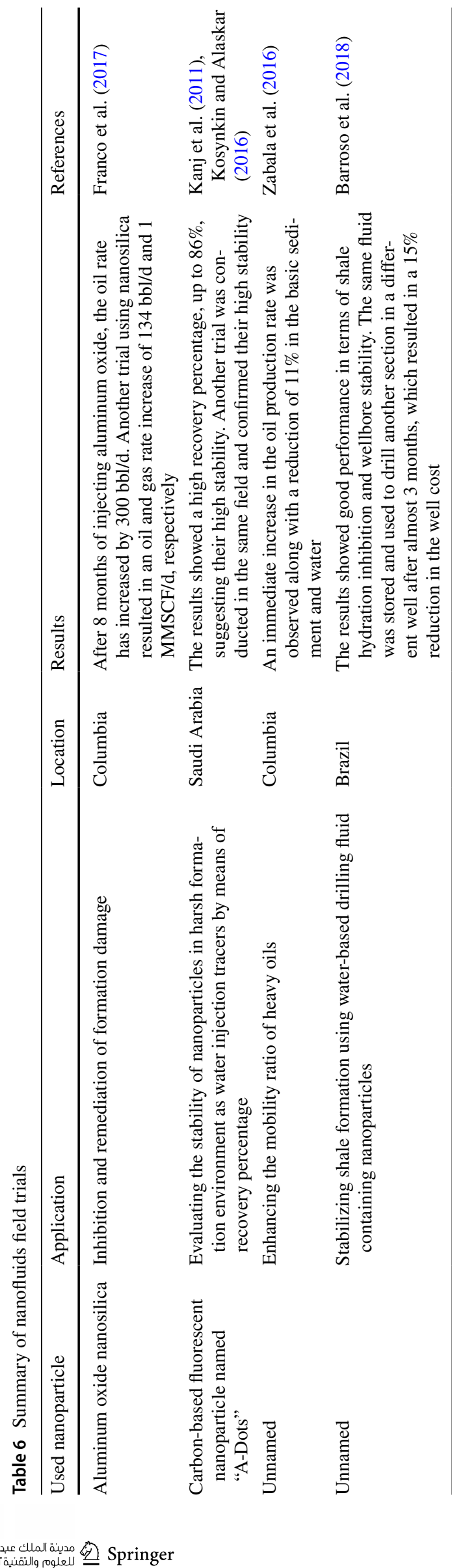

- Most of the investigated nanoparticles resulted in enhancing the mechanical properties of cement as well as providing a better control for the set time.

- In addition, a significant increase in oil recovery was observed when nanoparticles were applied for EOR application on a laboratory scale by means of wettability alteration and oil viscosity reduction.

- Despite a large number of laboratory-scale investigations published in the literature, only four filed trials with promising results were published to the best of our knowledge suggesting the need for more field trials.

- Based on the challenges discussed, more research should be conducted in order to reduce the cost of producing nanoparticles.

Open Access This article is licensed under a Creative Commons Attribution 4.0 International License, which permits use, sharing, adaptation, distribution and reproduction in any medium or format, as long as you give appropriate credit to the original author(s) and the source, provide a link to the Creative Commons licence, and indicate if changes were made. The images or other third party material in this article are included in the article's Creative Commons licence, unless indicated otherwise in a credit line to the material. If material is not included in the article's Creative Commons licence and your intended use is not permitted by statutory regulation or exceeds the permitted use, you will need to obtain permission directly from the copyright holder. To view a copy of this licence, visit http://creativecommons.org/licenses/by/4.0/.

\section{References}

Abdullahi MB, Rajaei K, Junin R, Bayat AE (2019) Appraising the impact of metal-oxide nanoparticles on rheological properties of HPAM in different electrolyte solutions for enhanced oil recovery. J Pet Sci Eng 172:1057-1068. https://doi.org/10.1016/j.petro 1.2018.09.013

Ahmed S, Ezeakacha CP, Salehi S (2018) Improvement in cement sealing properties and integrity using conductive carbon nano materials: from strength to thickening time. In: SPE annual technical conference and exhibition, 24-26 September, Dallas, Texas, USA. https://doi.org/10.2118/191709-MS

Ajulibe D, Ogolo N, Ikiensikimama S (2018) Viability of $\mathrm{SiO}_{2}$ Nanoparticles for enhanced oil recovery in the Niger Delta: a comparative analysis. In: SPE Nigeria annual international conference and exhibition, 6-8 August, Lagos, Nigeria. https://doi. org/10.2118/193423-MS

Alkhamis M, Imqam A (2018) New cement formulations utilizing graphene nano platelets to improve cement properties and long-term reliability in oil wells. In: SPE Kingdom of Saudi Arabia annual technical symposium and exhibition, 23-26 April, Dammam, Saudi Arabia. https://doi.org/10.2118/192342-MS

Almoshin AM, Alsharaeh E, Fathima A, Bataweel M (2018) A novel polymer nanocomposite graphene based gel for high temperature water shutoff applications. In: SPE Kingdom of Saudi Arabia annual technical symposium and exhibition, 23-26 April, Dammam, Saudi Arabia. https://doi.org/10.2118/192358-MS

Alomair OA, Matar KM, Alsaeed YH (2014) Nanofluids application for heavy oil recovery. In: SPE Asia Pacific oil \& gas conference 
and exhibition, 14-16 October, Adelaide, Australia. https://doi. org/10.2118/171539-MS

Alsaba MT, Al Fadhli A, Marafi A, Hussain A, Bander F, Al Dushaishi MF (2018) Application of nanoparticles in improving rheological properties of water based drilling fluids. In: SPE Kingdom of Saudi Arabia Annual technical symposium and exhibition, 23-26 April, Dammam, Saudi Arabia. https://doi.org/10.2118/19223 9-MS

Alvi MA, Belayneh M, Saasen A, Aadnøy BS (2018) The effect of micro-sized boron nitride $\mathrm{BN}$ and iron trioxide $\mathrm{Fe}_{2} \mathrm{O}_{3}$ Nanoparticles on the properties of laboratory bentonite drilling fluid. In: SPE Norway one day seminar, 18 April, Bergen, Norway. https:// doi.org/10.2118/191307-MS

Arab D, Kantzas A, Bryant SL (2018) Nanoparticle-enhanced surfactant floods to unlock heavy oil. In: SPE improved oil recovery conference, 14-18 April, Tulsa, Oklahoma, USA. https://doi. org/10.2118/190212-MS

Bai B (2008) Overview: eOR/IOR (January 2008). J Petrol Technol 60(01):42. https://doi.org/10.2118/0108-0042-JPT

Barroso AL, Marcelino CP, Leal AB, Odum DM, Lucena C, Masculo M, Castro F (2018) New generation nano technology drilling fluids application associated to geomechanic best practices: field trial record in Bahia, Brazil. In: Offshore technology conference, 30 April-3 May, Houston, Texas, USA. https://doi. org/10.4043/28731-MS

Barry MM, Jung Y, Lee JK, Phuoc TX, Chyu MK (2015) Fluid filtration and rheological properties of nanoparticle additive and intercalated clay hybrid bentonite drilling fluids. J Pet Sci Eng 127:338-346. https://doi.org/10.1016/j.petrol.2015.01.012

Chandler DL (2014) MIT News Office, April 29, 2014. http://news.mit. edu/2014/new-building-will-be-hub-for-nanoscale-research-0429. Accessed 3 Aug 2019

Chauhan G, Ojha K (2016) Synthesis of a bio-polymer nanocomposite fracturing fluid for HTHP application. In: Abu Dhabi international petroleum exhibition \& conference, 7-10 November, Abu Dhabi, UAE. https://doi.org/10.2118/183124-MS

Crews JB, Huang T (2008) Performance enhancements of viscoelastic surfactant stimulation fluids with nanoparticles. In: Europec/ EAGE conference and exhibition, 9-12 June 2008, Rome, Italy. https://doi.org/10.2118/113533-MS

Deshpande A, Patil R (2017) Applications of nanotechnology in oilwell cementing. In: SPE Middle East oil \& gas show and conference, 6-9 March, Manama, Kingdom of Bahrain. https://doi. org/10.2118/183727-MS

Ding Y, Zheng S, Meng X, Yang D (2018) Low salinity hot water injection with addition of nanoparticles for enhancing heavy oil recovery under reservoir conditions. In: SPE Western regional meeting, 22-26 April, Garden Grove, California, USA. https:// doi.org/10.2118/190132-MS

Druetta P, Raffa P, Picchioni F (2018) Plenty of room at the bottom: nanotechnology as solution to an old issue in enhanced oil recovery. Appl Sci 8(12):2596. https://doi.org/10.3390/app8122596

Elshawaf M (2018a) Investigation of Graphene oxide nanoparticles effect on heavy oil viscosity. In: SPE annual technical conference and exhibition, 24-26 September, Dallas, Texas, USA. https://doi. org/10.2118/194037-STU

Elshawaf M (2018b) Consequence of graphene oxide nanoparticles on heavy oil recovery. In: SPE Kingdom of Saudi Arabia Annual technical symposium and exhibition, 23-26 April, Dammam, Saudi Arabia. https://doi.org/10.2118/192245-MS

Fakoya MF, Shah SN (2018) Effect of silica nanoparticles on the rheological properties and filtration performance of surfactant-based and polymeric fracturing fluids and their blends. SPE Drill Complet 33(02):100-114. https://doi.org/10.2118/163921-PA

Folio E, Ogunsola O, Melchert E, Frye E (2018) Produced water treatment $R \& D$ : developing advanced, cost-effective treatment technologies. In: SPE/AAPG/SEG unconventional resources technology conference, 23-25 July, Houston, Texas, USA. https ://doi.org/10.15530/URTEC-2018-2886718

Franco CA, Zabala R, Cortés FB (2017) Nanotechnology applied to the enhancement of oil and gas productivity and recovery of Colombian fields. J Pet Sci Eng 157:39-55. https://doi.org/10.1016/j. petrol.2017.07.004

Gbadamosi AO, Junin R, Oseh JO, Agi A, Yekeen N, Abdalla Y, Ogiriki S, Yusuff AS (2018) improving hole cleaning efficiency using nanosilica in water-based drilling mud. In: SPE Nigeria annual international conference and exhibition, 6-8 August, Lagos, Nigeria. https://doi.org/10.2118/193401-MS

Gerogiorgis DI, Reilly S, Vryzas Z, Kelessidis VC (2017) Experimentally validated first-principles multivariate modeling for rheological study and design of complex drilling nanofluid systems. In: SPE/IADC drilling conference and exhibition, 14-16 March, The Hague, The Netherlands. https://doi. org/10.2118/184692-MS

Giraldo LJ (2018) Janus nanoparticles for enhanced oil recovery EOR: Reduction of Interfacial Tension. In: SPE annual technical conference and exhibition, 24-26 September, Dallas, Texas, USA. https ://doi.org/10.2118/194033-STU

Gribbin J, Gribbin M (2018) Richard Feynman: a life in science. Math Gaz 82(494):327. https://doi.org/10.2307/3620438

Guo C, Bai B, Wei M, He X, Wu Y-S (2013) Study on Gas flow in nano pores of shale gas reservoir. In: SPE unconventional resources conference, 5-7 November, Calgary, Alberta, Canada. https://doi. org/10.2118/167179-MS

Hafiz A, Kamal M, Al-Harthi M, Elkatatny S, Murtaza M (2018) Synthesis and experimental investigation of novel CNT-polymer nanocomposite to enhance borehole stability at high temperature drilling applications. In: SPE Kingdom of Saudi Arabia annual technical symposium and exhibition, 23-26 April, Dammam, Saudi Arabia. https://doi.org/10.2118/192352-MS

Hassani SS, Amrollahi A, Rashidi A, Soleymani M, Rayatdoost S (2016) The effect of nanoparticles on the heat transfer properties of drilling fluids. J Pet Sci Eng 146:183-190. https://doi. org/10.1016/j.petrol.2016.04.009

Hogeweg AS, Hincapie RE, Foedisch H, Ganzer L (2018) Evaluation of aluminium oxide and titanium dioxide nanoparticles for EOR applications. In: SPE Europec featured at 80th EAGE conference and exhibition, 11-14 June, Copenhagen, Denmark. https://doi. org/10.2118/190872-MS

Ibrahim AF, Nasr-El-Din H (2018) An experimental study for the using of nanoparticle/VES stabilized $\mathrm{CO}_{2}$ foam to improve the sweep efficiency in EOR applications. In: SPE annual technical conference and exhibition, 24-26 September, Dallas, Texas, USA. https ://doi.org/10.2118/191534-MS

Ismail AR, Aftab A, Ibupoto ZH, Zolkifile N (2016) The novel approach for the enhancement of rheological properties of waterbased drilling fluids by using multi-walled carbon nanotube, nanosilica and glass beads. J Pet Sci Eng 139:264-275. https://doi. org/10.1016/j.petrol.2016.01.036

Jafariesfad N, Gong Y, Geiker MR, Skalle P (2016) Nano-sized MgO with engineered expansive property for oil well cement systems. In: SPE Bergen one day seminar, 20 April, Grieghallen, Bergen, Norway. https://doi.org/10.2118/180038-MS

Jalal M, Mansouri E, Sharifipour M, Pouladkhan A (2012) Mechanical, rheological, durability and microstructural properties of high performance self-compacting concrete containing $\mathrm{SiO}_{2}$ micro and nanoparticles. Mater Des 34:389-400. https://doi.org/10.1016/j. matdes.2011.08.037

Joshua J (2014) Advanced slim hole logging tools for precise mapping of hydrocarbons and lowering drilling cost. In: International petroleum technology conference, 19-22 January, Doha, Qatar. https://doi.org/10.2523/IPTC-17310-MS

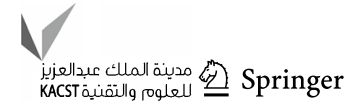


Kanj M Y, Funk JJ, Al-Yousif Z (2009) Nanofluid coreflood experiments in the ARAB-D. In: SPE Saudi Arabia section technical symposium, 9-11 May, Al-Khobar, Saudi Arabia. https://doi. org/10.2118/126161-MS

Kanj MY, Rashid MH, Giannelis E (2011) Industry First field trial of reservoir nanoagents. In: SPE Middle East oil and gas show and conference, 25-28 September, Manama, Bahrain. https://doi. org/10.2118/142592-MS

Khajehpour M, Etminan SR, Goldman J, Wassmuth F, Bryant S (2016) Nanoparticles as foam stabilizer for steam-foam process. In: SPE EOR conference at oil and gas West Asia, 21-23 March, Muscat, Oman. https://doi.org/10.2118/179826-MS

Kim HC, Fthenakis V (2012) Life Cycle energy and climate change implications of nanotechnologies. J Ind Ecol 17(4):528-541. https ://doi.org/10.1111/j.1530-9290.2012.00538.x

Kong X, Ohadi M (2010) Applications of micro and nano technologies in the oil and gas industry-overview of the recent progress. In: Abu Dhabi international petroleum exhibition and conference, 1-4 November, Abu Dhabi, UAE. https://doi.org/10.2118/138241-MS

Kosynkin D, Alaskar M (2016) Oil Industry first interwell trial of reservoir nanoagent tracers. In: SPE annual technical conference and exhibition, 26-28 September, Dubai, UAE. https://doi. org/10.2118/181551-MS

Kumar N, Kumar A, Kumar S (2018) Effect of synthesized AMPSg-clay/CuO nanocomposite on WBDFS for challenging formations. In: IADC/SPE Asia Pacific drilling technology conference and exhibition, 27-29 August, Bangkok, Thailand. https://doi. org/10.2118/191105-MS

Lau HC, Yu M, Nguyen QP (2017) Nanotechnology for oilfield applications: challenges and impact. J Pet Sci Eng 157:1160-1169. https://doi.org/10.1016/j.petrol.2017.07.062

Lecolier E, Herzhaft B, Rousseau L, Neau L, Quillien B, Kieffer J (2005) Development of a nanocomposite gel for lost circulation treatment. In: SPE European formation damage conference, 25-27 May, Sheveningen, The Netherlands. https://doi. org/10.2118/94686-MS

Li H, Xiao H, Ou J (2004) A study on mechanical and pressure-sensitive properties of cement mortar with nanophase materials. Cem Concr Res 34(3):435-438. https://doi.org/10.1016/j.cemco nres.2003.08.025

Li Y, Guo J, Wang S, Yang R, Lu Q (2019) Reducing hydroxypropyl guar gum adsorption on rock by silica nanoparticles for tight reservoir damage remediation. In: International petroleum technology conference, 26-28 March, Beijing, China. https://doi. org/10.2523/IPTC-19561-MS

Mahmoud O, Nasr-El-Din HA, Vryzas Z, Kelessidis V (2018) Effect of ferric oxide nanoparticles on the properties of filter cake formed by calcium bentonite-based drilling muds. SPE Drill Complet 33(04):363-376. https://doi.org/10.2118/184572-PA

Mangadlao J, Cao P, Advincula R (2015) Smart cements and cement additives for oil and gas operations. J Pet Sci Eng 129:63-76. https ://doi.org/10.1016/j.petrol.2015.02.009

Minakov AV, Zhigarev VA, Mikhienkova EI, Neverov AL, Buryukin FA, Guzei DV (2018) The effect of nanoparticles additives in the drilling fluid on pressure loss and cutting transport efficiency in the vertical boreholes. J Pet Sci Eng 171:1149-1158. https://doi. org/10.1016/j.petrol.2018.08.032

Nabhani N, Tofighi A (2010) The assessment of health, safety and environmental risks of nanoparticles and how to control their impacts. In: SPE international conference on health, safety and environment in oil and gas exploration and production, 12-14 April, Rio de Janeiro, Brazil. https://doi.org/10.2118/127261-MS

Nasr-El-Din HA, Gurluk MR, Crews JB (2013) Enhancing the performance of viscoelastic surfactant fluids using nanoparticles. In: EAGE annual conference and exhibition incorporating SPE
Europec, 10-13 June, London, UK. https://doi.org/10.2118/16490 0 -MS

National Nanotechnology Initiative (2000) What is nanotechnology? https://www.nano.gov/nanotech-101/what/definition Accessed 3 Aug 2019

National Nanotechnology Initiative (2019) https://www.nano.gov/you/ standards. Accessed 3 Aug 2019

Nazari A, Riahi S (2011) Improvement compressive strength of concrete in different curing media by $\mathrm{Al}_{2} \mathrm{O}_{3}$ nanoparticles. Mater Sci Eng A 528(3):1183-1191. https://doi.org/10.1016/j. msea.2010.09.098

NNI, US (2018) The national nanotechnology initiative supplement to the President's 2019 Budget. https://www.nano.gov/sites/default/ files/NNI-FY19-Budget-Supplement.pdf Accessed 3 Aug 2019

Norio T (1974) On the basic concept of 'nano-technology. In: Proceedings of the international conference on production engineering, Tokyo. Japan Society of Precision Engineering

Ogolo NA, Olafuyi OA, Onyekonwu MO (2012) Enhanced oil recovery using nanoparticles. In: SPE Saudi Arabia section technical symposium and exhibition, 8-11 April, Al-Khobar, Saudi Arabia. https://doi.org/10.2118/160847-MS

Pan D, Vipulanandan C, Amani N, Reddy SA, Chockalingam CG (2018) Effects of nanoclay on the rheological properties and resistivity of synthetic based drilling fluids under high temperature. In: Offshore technology conference, 30 April-3 May, Houston, Texas, USA. https://doi.org/10.4043/28751-MS

Pandey A, Telmadarreie A, Trifkovic M, Bryant S (2018) Cellulose nanocrystal stabilized emulsions for conformance control and fluid diversion in porous media. In: SPE annual technical conference and exhibition, 24-26 September, Dallas, Texas, USA. https ://doi.org/10.2118/191609-MS

Pang X, Boul PJ, Cuello Jimenez W (2014) Nanosilicas as accelerators in oilwell cementing at low temperatures. SPE Drill Complet 29(1):98-105. https://doi.org/10.2118/168037-PA

Parizad A, Shahbazi K, Tanha AA (2018) Enhancement of polymeric water-based drilling fluid properties using nanoparticles. J Pet Sci Eng 170:813-828. https://doi.org/10.1016/j.petrol.2018.06.081

Patil R C, Deshpande A (2012) Use of nanomaterials in cementing applications. In: SPE international oilfield nanotechnology conference and exhibition, 12-14 June, Noordwijk, The Netherlands. https://doi.org/10.2118/155607-MS

Perween S, Beg M, Shankar R, Sharma S, Ranjan A (2018) Effect of zinc titanate nanoparticles on rheological and filtration properties of water based drilling fluids. J Pet Sci Eng 170:844-857. https:// doi.org/10.1016/j.petrol.2018.07.006

Peyvandi A, Taleghani AD, Soroushian P, Cammarata R (2017) The use of low-cost graphite nanomaterials to enhance zonal isolation in oil and gas wells. In: SPE annual technical conference and exhibition, 9-11 October, San Antonio, Texas, USA. https://doi. org/10.2118/187105-MS

Piantanida M, Veneziani M, Fresca Fantoni R, Mickelson W, Milgrome O, Sussman A, Zhou Q, Ackerman I, Zettl A (2013) An innovative wireless $\mathrm{H}_{2} \mathrm{~S}$ sensor based on nanotechnology to improve safety in oil and gas facilities. In: SPE Offshore Europe oil and gas conference and exhibition, 3-6 September, Aberdeen, UK. https://doi. org/10.2118/166544-MS

Pinzón DM (2018) Rheological Demonstration of heavy oil viscosity reduction by $\mathrm{NiO} / \mathrm{SiO}_{2}$ nanoparticles-assisted ultrasound cavitation. In: SPE Annual technical conference and exhibition, 24-26 September, Dallas, Texas, USA. https://doi.org/10.2118/19403 0 -STU

Pourafshary P, Azimpour S, Motamedi P, Samet M, Taheri S, Bargozin H, Hendi S (2009) Priority assessment of investment in development of nanotechnology in upstream petroleum industry. In: SPE Saudi Arabia section technical symposium, 9-11 May, Al-Khobar, Saudi Arabia. https://doi.org/10.2118/126101-MS 
Santra AK, Boul P, Pang X (2012) Influence of nanomaterials in oilwell cement hydration and mechanical properties. In: SPE international oilfield nanotechnology conference and exhibition, 12-14 June, Noordwijk, The Netherlands. https://doi.org/10.2118/156937-MS

Seland A, Torleiv B, Surinder M, Bakke R (1992) Membrane filtration of seawater for oil reservoir injection. In: SPE annual technical conference and exhibition, 4-7 October, Washington, DC. https ://doi.org/10.2118/24805-MS

Sensoy T, Chenevert ME, Sharma M (2009) Minimizing water invasion in shales using nanoparticles. In: SPE annual technical conference and exhibition, 4-7 October, New Orleans, Louisiana. https://doi. org/10.2118/124429-MS

ShamsiJazeyi H, Miller CA, Wong MS, Tour JM, Verduzco R (2014) Polymer-coated nanoparticles for enhanced oil recovery. J Appl Polym Sci 131:40576. https://doi.org/10.1002/app.40576

Shen Z, Sheng J (2016) Experimental study of asphaltene aggregation during $\mathrm{CO}_{2}$ and $\mathrm{CH}_{4}$ injection in shale oil reservoirs. In: SPE improved oil recovery conference, 11-13 April, Tulsa, Oklahoma, USA. https://doi.org/10.2118/179675-MS

Shih J, Chang T, Hsiao T (2006) Effect of nanosilica on characterization of Portland cement composite. Mater Sci Eng A 424(12):266-274. https://doi.org/10.1016/j.msea.2006.03.010

Singh P, Bhat S (2006) Nanologging: use of nanorobots for logging. In: SPE eastern regional meeting, 11-13 October, Canton, Ohio, USA. https://doi.org/10.2118/104280-MS

Singh R, Tong S, Panthi K, Mohanty K (2018) Nanoparticle-encapsulated acids for stimulation of calcite-rich shales. In: SPE/AAPG/ SEG unconventional resources technology conference, 23-25 July, Houston, Texas, USA. https://doi.org/10.15530/URTEC $-2018-2897114$

Sudarshan TS, Kalyanaraman R, Handsy C (2001) In-situ nanosensors for the detection of corrosion of metal components on military ground vehicles. In: NACE international, 11-16 March, Houston, Texas. Paper No. NACE-01564

Suresh R, Kuznetsov O, Agrawal D, Darugar Q, Khabashesku V (2018) Reduction of surfactant adsorption in porous media using silica nanoparticles. In: Offshore technology conference, 30 April-3 May, Houston, Texas, USA. https://doi.org/10.4043/28879-MS

Ventura D, Murugesan S, Kuznetsov O, Mazyar O, Khabashesku V, Darugar Q (2017) Nanotechnology-based solution for offshore zinc removal water treatment technology. In: Offshore technology conference, 1-4 May, Houston, Texas, USA. https://doi. org/10.4043/27610-MS

Vipulanandan C, Krishnamoorti R, Mohammed A, Boncan V, Narvaez G, Head B, Pappas JM (2015) Iron nanoparticle modified smart cement for real time monitoring of ultra deepwater oil well cementing applications. In: Offshore technology conference,
04-07 May, Houston, Texas, USA. https://doi.org/10.4043/25842 -MS

Vipulanandan C, Mohammed A, Ganpatye AS (2018a) Smart cement performance enhancement with nano $\mathrm{Al}_{2} \mathrm{O}_{3}$ for real time monitoring applications using vipulanandan models. In: Offshore technology conference, 30 April-3 May, Houston, Texas, USA. https:// doi.org/10.4043/28880-MS

Vipulanandan C, Mohammed A, Samuel RG (2018b) Fluid loss control in smart bentonite drilling mud modified with nanoclay and quantified with Vipulanandan fluid loss model. In: Offshore technology conference, 30 April-3 May, Houston, Texas, USA. https://doi. org/10.4043/28947-MS

Wang X, Chen M, Jin Y, Lu Y, Yang S, Liang C (2018) Decreasing water invasion into shale using hydrophilic sulfonated silica nanoparticles. In: 52nd US rock mechanics/geomechanics symposium, 17-20 June, Seattle, Washington. ARMA-2018-034

Wei B, Qinzhi L, Wang Y, Gao K, Pu W, Sun L (2018) An experimental study of enhanced oil recovery EOR using a green nano-suspension. In: SPE improved oil recovery conference, 14-18 April, Tulsa, Oklahoma, USA. https://doi.org/10.2118/190283-MS

Xu Z, Jin Y, Chen M (2013) Ultrasonic Curable nanoparticles strengthening technique while drilling. In: SPE annual technical conference and exhibition, 30 September-2 October, New Orleans, Louisiana, USA. https://doi.org/10.2118/166355-MS

Yang X, Shang Z, Liu H, Cai J, Jiang G (2017) Environmental-friendly salt water mud with nano- $\mathrm{SiO}_{2}$ in horizontal drilling for shale gas. J Pet Sci Eng 156:408-418. https://doi.org/10.1016/j.petro 1.2017.06.022

Yuan B, Moghanloo RG (2018) Nanofluid precoating: an effective method to reduce fines migration in radial systems saturated with two mobile immiscible fluids. SPE J 23(03):0998-1018. https:// doi.org/10.2118/189464-PA

Zabala R, Franco CA, Cortés FB (2016) Application of nanofluids for improving oil mobility in heavy oil and extra-heavy oil: a field test. In: SPE improved oil recovery conference, 11-13 April, Tulsa, Oklahoma, USA. https://doi.org/10.2118/179677-MS

Zargartalebi M, Barati N, Kharrat R (2014) Influences of hydrophilic and hydrophobic silica nanoparticles on anionic surfactant properties: interfacial and adsorption behaviors. J Pet Sci Eng 119:3643. https://doi.org/10.1016/j.petrol.2014.04.010

Publisher's Note Springer Nature remains neutral with regard to jurisdictional claims in published maps and institutional affiliations.

N 